\title{
Horizontal Profile of Facial Skeletons from the Himrin Basin, Iraq
}

\author{
Yo WADA \\ Department of Anatomy, Hyogo College of Medicine
}

\begin{abstract}
This paper describes the horizontal profile of facial skeletons from the Himrin Basin, Iraq. The horizontal profiles both of the face and anterior face were evaluated using a total of 22 width and depth measurements. Ninety-five skulls which included dolichocranic (Mediterranean) and brachycranic (Alpine) racial types were utilized. Uni- and multivariate analyses were applied to estimate racial and sexual variations both in the faces and anterior faces, to confirm racial type based on the morphology of the face, to evaluate population characteristics, and to ascertain the racial positions of the two racial types in the world.

Employing multivariate analyses, horizontal profiles of the maxillary region of the face could be used to discriminate between the two racial types in males, while a horizontal profile of the maxillary region of the anterior face could be used for females. Sexual variations within racial types were determined by size differences both in the overall regions of the face and in the frontal region of the anterior face.

By applying univariate analyses, the racial type in males could be determined by size differences in the width of the postero-basal region of the face, namely, the cranial base. The racial type in females could be determined by size differences both in the depth of the maxillary region of the anterior face and in the width of the cranial base.

Employing multivariate analyses, comparative studies clearly indicated that the two racial types from the Himrin Basin were members of the Caucasoid race.
\end{abstract}

Keywords Facial skeleton, Horizontal profiles, Dolichocranic racial type, Brachycranic racial type, Caucasoid race, Himrin Basin

\section{Introduction}

Human skeletal remains were unearthed from the Himrin Basin, Iraq in 1978-80
(FUJII, 1981). There were too many samples, they came from too wide an area, and had too much morphological variations in the skulls to permit evaluation of physical charac-

Article No. 8901 Received July 17, 1989 
teristics and racial affinity of the population. Studies were therefore planned to analyze the wide morphological variations in the skulls, evaluate population characteristics, and then investigate the racial position of the population in West Asia and neighboring countries.

From previous studies (WADA, 1986) it was deduced that the skulls from the Himrin Basin were a mixture of two racial types, namely, dolichocranic and brachycranic. The dolichocranic racial type metrically had dolichocranic, acrocranic, mesoconchic, and mesorrhine characteristics. On the other hand, the brachycranic were distinguished metrically by brachycranic, tapeinocranic, hypsiconchic, and leptorrhine characteristics. Comparative studies have indicated that the dolichocranic racial type belongs to the Mediterranean race of the Caucasoid race, and the brachycranic to the Alpine race.

Nevertheless, a number of new problems arose from these studies. How do we classify postcranial skeletons without skulls into the two racial types? How can we be convinced that the racial type division based on variations in the skulls are truly accurate? How can we find other discriminators for the classification of the two racial types? How can we describe the population characteristics of postcranial skeletons which are limited in quantity?

The present study attempted to estimate racial and sexual variations in the facial skeletons, to confirm the racial type based on the morphology of the face, to evaluate population characteristics, and then to investigate the racial positions of the two racial types in the world, especially the affinity between the brachycranic racial type and the Mongoloid race.

\section{Materials and Methods}

Ninety-five adult facial skeletons from the Islamic period were utilized in this study. They had been excavated from Tell Gubba, Songor-A, B, and C, and Zuveidi in the Himrin Basin, Iraq, and from the Ashur site in the northern region of Iraq (Fig. 1) by an archaeological expedition from Kokushikan University in 1978-80 (FUJII, 1981; WADA, 1986).

All samples were re-examined to confirm their sex. The sex of five skulls was revised following reconstruction and repair of their postcranial skeletons. There is an anthropological belief that the sex determination of skulls should be based on sexual and morphological variations within the race or racial type. Re-examination was unavoidable

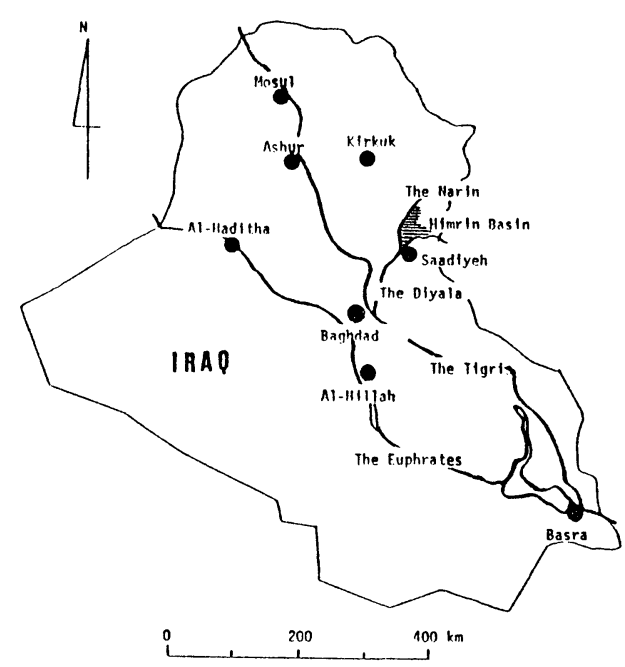

Fig. 1. Geographic locations of the Himrin Basin and Ashur in Iraq. The Himrin Basin lies about $130 \mathrm{~km}$ northeast from the capital Baghdad, and its historic sites are located between the Diyala and Narin Rivers. Ashur lies about $300 \mathrm{~km}$ northwest from the capital. Its historic site is located on the right bank of the Tigris. 
since the samples were a mixture of two racial types.

Sex was determined based on morphology both of the hip bones and skulls in the same manner as before (EHRICH, 1939; MARTIN and SAller, 1957; El-NAJJAR and MC William, 1978; BROTHWELl, 1981; WADA, 1986). A different procedure was employed in this study when the skull was not accompanied by its hip bones. Three skulls which were accompanied by their hip bones or showed sexual dimorphism within a racial type were first chosen from each of the sexual and racial types. Skulls not accompanied by hip bones were intimately and directly compared with the selected twelve.

As a result, the sex of twelve skulls was revised, including five resulting from the reconstruction of the postcranial skeletons. Dividing the facial skeletons into the two racial types according to their previously determined racial types, 32 males and 22 females were of the dolichocranic racial type, while 21 males and 20 females belonged to the brachycranic.

The supero-posterior region of the facial skeleton is contiguous with the cranial skeleton. The upper boundary is a line connecting the supraorbital margin on each side, and the posterior is a line connecting the external acoustic meatuses.

The facial skeleton, referred to as the face in this paper, is separated from the cranial skeleton by a plane connecting both lines. The present study investigated morphological variations both in the faces and anterior faces. The anterior face is separated from the face by a plane connecting the frontomalare orbitale and zygomaxillare anterius on each side.

A protocol comprising 28 measurements was established to study horizontal profiles both for the face and anterior face. Eight measurements were quoted from the previous work (WADA, 1986), namely, the upper facial and nasal heights, minimum frontal and bizygomatic breadths, and total facial, nasal, alveolar, and nasalia profile angles. The other 20, 5 in width and 15 in depth, were measured for the first time in this study.

The 4 width measurements were the distances between the porion, frontomalare orbitale, midorbital point, and zygomaxillare anterius on each side. The other was the simotic chord, namely, the minimum transverse width across the two nasal bones. Those distances were termed respectively the biporionic, biorbital, and bizygomaxillary breadths.

Eight depth measurements were developed for the face. They were the subtenses from the glabella, nasion, rhinion, subspinale, frontotemporale, frontomalare orbitale, midorbital point, and zygomaxillare anterius to the biporionic breadth. The other measurements were for the anterior face. They were the subtenses from the glabella, nasion, maxillofrontale, and rhinion to the biorbital breadth, from the median ridge of the nasalia to the simotic chord, from the subspinale to the bizygomaxillary breadth, and from the rhinion to the midorbital breadth.

The following defines the terminology for subtense measurements in the present paper. A subtense for the face is represented by the name of the landmark, such as the nasion subtense or subspinale subtense. On the other hand, that for the anterior face is distinguished by the names both of the landmark and standard width, such as the nasion biorbital subtense or subspinale bizygomaxillary subtense.

These new measurements were both based on facial flatness measurements by Woo and 
Morant (1934), YAmAGUChI (1973, 1980), and DoDo (1986), and based on radii from facial landmarks to the transmeatal axis by Howells (1973). The porion, glabella, nasion, rhinion, and frontotemporale among the facial landmarks were based on definitions by MARTIN and SALLER (1957), the frontomalare orbitale, zygomaxillare anterius, and subspinale on definitions by YAMAGUCHI (1973), Howells (1973), and DoDo (1986), and the midorbital point on definition by WOO and MORANT (1934).

The measurement procedures were as follows. All landmarks were first marked with a sharp pencil. Distances between them were measured to an accuracy of $0.1 \mathrm{~mm}$ using vernier calipers. The subtenses were then computed from the distances according to trigonometric formulae (YAMAGUCHI, 1973; Howells, 1973; DoDo, 1986).

In the univariate analyses, the Fisher test, Student t-test, and Welch t'-test were applied to respective measurements to evaluate racial and sexual differences both in the faces and anterior faces $(* * *: p<0.001, * *$ : $\mathrm{p}<0.01$, and $*: \mathrm{p}<0.05)$. Principal component analysis was utilized in multivariate analyses both for estimating the racial and sexual variations, and for comparing the two racial types with a number of different populations.

Thirteen measurements were used in the multivariate analysis for study of the face, namely, the minimum frontal, biorbital, bizygomaxillary, bizygomatic, and biporionic breadths, the glabella, nasion, subspinale, frontotemporale, frontomalare, and zygomaxillare subtenses, and the upper facial and nasal heights. Six measurements, namely, the biorbital and bizygomaxillary breadths, the glabella, nasion, and maxillofrontale biorbital subtenses, and the sub- spinale bizygomaxillary subtense, were applied for study of the anterior face.

The following is an outline of the present study. Racial and sexual variations both in the faces and anterior faces were first estimated using principal component analyses. The faces of the two racial types were observed to confirm their racial type based on morphology. Racial and sexual differences both in the faces and anterior faces were analyzed using univariate analyses. Finally, both the face and anterior face of the two racial types were compared with those of different populations using principal component analyses. All the comparative populations were quoted both from MARTIN and SALLER (1959), and from YAMAGUCHI (1973).

\section{Results}

\section{Racial and sexual variations in the face}

Five types of morphological variations in the faces were determined according to groupings based on racial and sexual types. The first was racial variation based on the two racial types in males, and the second was based on the two in females. The third was sexual variation based on the dolichocranic racial type, and the fourth was based on the brachycranic. The fifth included both racial and sexual variations for all racial and sexual types. The first and second groupings were represented respectively by males and females in the present paper, while the third, fourth, and fifth were described as dolichocranics, brachycranics, and males and females.

Fifty-five faces were utilized in these estimates. Fifteen males and 12 females belonged to the dolichocranic racial type. 
Table 1. Factor loading of the principal components showing both racial and sexual variations in the faces

\begin{tabular}{|c|c|c|c|c|c|c|}
\hline Grouping & \multirow{2}{*}{$\begin{array}{c}\text { Males } \\
\text { 2nd. }\end{array}$} & \multirow{2}{*}{$\begin{array}{c}\text { Females } \\
1 \text { st. }\end{array}$} & \multirow{2}{*}{$\begin{array}{c}\text { Dolicho- } \\
\text { cranics } \\
\text { lst. }\end{array}$} & \multirow{2}{*}{$\begin{array}{c}\text { Brachy- } \\
\text { cranics } \\
\text { lst. }\end{array}$} & \multicolumn{2}{|c|}{$\begin{array}{l}\text { Males } \\
\text { and females }\end{array}$} \\
\hline Measurements and Components & & & & & 1st. & 2nd. \\
\hline 1. Minimum frontal & 0.36 & 0.40 & 0.22 & 0.59 & 0.46 & 0.49 \\
\hline 2. Biorbital breadth & 0.45 & 0.68 & 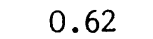 & 0.7 & 0.73 & 0.41 \\
\hline 3. Bizygomaxillary breadth & 0.48 & 0.50 & 0.38 & 0.68 & 0.54 & 0.52 \\
\hline 4. Bizygomatic breadth & 0.50 & 0.7 & 0.86 & 0.72 & 0.82 & 0.38 \\
\hline 5. Biporionic breadth & 0.59 & 0.78 & 0.73 & 0.48 & 0.67 & 0.45 \\
\hline 6. Upper facial height & 0.35 & 0.36 & 0.49 & 0.77 & 0.66 & 0.28 \\
\hline 7. Nasal height & 0.33 & 0.64 & 0.66 & 0.66 & 0.69 & 0.24 \\
\hline 8. Glabella subtense & -0.48 & 0.84 & 0.93 & 0.85 & 0.88 & -0.34 \\
\hline 9. Nasion subtense & -0.41 & 0.85 & 0.93 & 0.87 & 0.88 & -0.33 \\
\hline 10. Subspinale subtense & -0.62 & 0.31 & 0.81 & 0.66 & 0.61 & -0.58 \\
\hline 11. Frontotemporale subtense & -0.16 & 0.80 & 0.86 & 0.81 & 0.85 & -0.21 \\
\hline 12. Frontomalare subtense & -0.37 & 0.86 & 0.84 & 0.83 & 0.83 & -0.34 \\
\hline 13. Zygomaxillare subtense & -0.59 & 0.48 & 0.77 & 0.66 & 0.67 & -0.56 \\
\hline
\end{tabular}

On the other hand, 13 males and 15 females belonged to the brachycranic. They were chosen on the condition that they had both a complete set of 11 measurements for the skull in the previous study (WADA, 1986), and a complete set of 13 measurements for the face in this study.

Principal component analysis was applied to the 13 measurements of the faces for each group. When a component enabled us to discriminate between the sexual types or between the racial types with statistical significance $(p<0.05)$ by univariate analyses, it was noted and tabulated (Table 1 ).

\section{Males}

The second component showed a bipolar loading pattern both with 4 breadth variables in the positive direction and 4 subtense variables in the negative. The positive were the biporionic, bizygomatic, bizygomaxillary, and biorbital breadths, and the negative were the subspinale, zygomaxillare, glabella, and nasion subtenses.
This component represented an axis of shape variation that contrasted the overall widths with the depths, particularly of the maxillary region. An average component score $(-0.74)$ for the dolichocranic racial type in males was smaller than that $(+0.86)$ for the brachycranic in males $\left(t=2.91^{* *}\right)$.

This component accounted for $20.62 \%$ of the entire variation, while the accumulated proportion of the first three accounted for $77.47 \%$.

\section{Females}

The first component showed a unipolar loading pattern with 9 subtense, breadth, and height variables loaded highly in the positive direction. It represented an axis of overall size variation. An average component score $(-1.84)$ for the dolichocranic racial type in females was smaller than that $(+1.47)$ for the brachycranic in females $\left(\mathrm{t}=4.85^{* * *}\right)$.

This component accounted for $44.40 \%$ of the entire variation, while the accumulated 
proportion of the first three accounted for $77.78 \%$.

\section{Dolichocranics}

The first component showed a unipolar loading pattern with 10 subtense, breadth, and height variables loaded highly in the positive direction. It represented an axis of overall size variation. An average component score $(+1.80)$ for the dolichocranic racial type in males was larger than that $(-2.25)$ for the dolichocranic in females $\left(t^{\prime}\right.$ $=6.64^{* * *}$ ).

This component accounted for $53.48 \%$ of the entire variation, while the accumulated proportion of the first three accounted for $84.13 \%$.

\section{Brachycranics}

The first component showed a unipolar loading pattern with 12 subtense, breadth, and height variables loaded highly in the positive direction. It represented an axis of overall size variation. An average component score $(+1.40)$ for the brachycranic racial type in males was larger than that $(-1.21)$ for the brachycranic in females $(t=$ $2.98 * *)$.

This component accounted for $52.95 \%$ of the entire variation, while the accumulated proportion of the first three accounted for $78.33 \%$.

\section{Males and females}

The first component showed a unipolar loading pattern with 12 subtense, breadth, and height variables loaded highly in the positive direction. It represented an axis of overall size variation. Average component scores both for racial and sexual types lined up in descending order were: the brachycranic in males $(+1.97)$, dolichocranic in males $(+1.11)$, brachycranic in females $(-0.33)$, and dolichocranic in females $(-3.10)$. The component scores for the two racial types in males were larger than those for the two in the corresponding females (dolichocranic: $t^{\prime}=6.63^{* * *}$, brachycranic: $t=$ $\left.3.01^{* *}\right)$. The component score for the dolichocranic racial type in females was smaller than that for the brachycranic in females $\left(t=4.72^{* * *}\right)$.

The second component showed a bipolar loading pattern both with 4 breadth variables in the positive direction and two subtense variables in the negative. The positive were the bizygomaxillary, minimum frontal, biporionic, and biorbital breadths, and the negative were the subspinale and zygomaxillare subtenses. They represented an axis of shape variation that contrasted the overall widths with the depth of the maxillary region. Average component scores both for racial and sexual types lined up in descending order were: the brachycranic in males $(+0.60)$, brachycranic in females $(+0.57)$, dolichocranic in females $(-0.25)$, and dolichocranic in males $(-0.89)$. In males, the component score for the brachycranic racial type was larger than that for the dolichocranic $\left(t=2.89^{* *}\right)$. The first and second components accounted respectively for $52.55 \%$ and $16.92 \%$ of the entire variation, while the accumulated proportion of the first three accounted for $78.87 \%$.

Figure 2 shows the similarities in the first two components both between the sexual types, and between the racial types. The two racial types in males are plotted on the right in the figure, and the two in females on the left. In males, the brachycranic racial type is clustered over the dolichocranic, and the brachycranic in females between the two in males and the dolichocranic in 


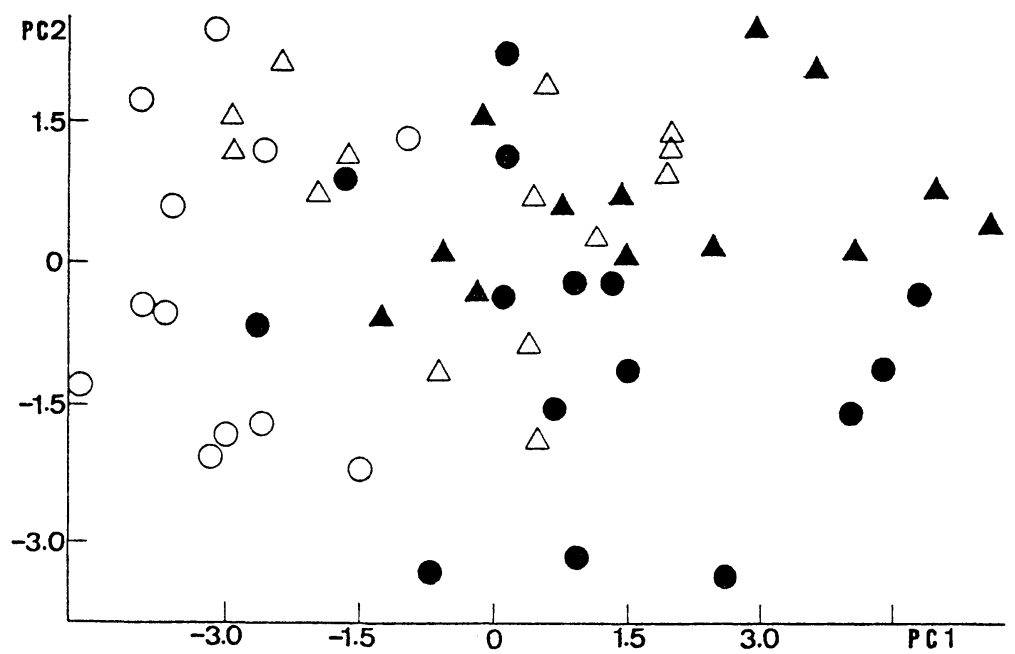

Fig. 2. Similarities in the faces between both racial and sexual types. Black circles show males of the dolichocranic racial type, and white circles females. Black triangles show males of the brachycranic racial type, and white triangles females.

females.

In males, the dolichocranic racial type was discriminated from the brachycranic by the ratio of the depth of the maxillary region of the face to the overall widths, namely, horizontal profiles of the maxillary region of the face. On the other hand, both racial variations in females and sexual variations in the two racial types were caused by overall size differences in the faces.

\section{Racial and sexual variations in the anterior face}

Five morphological variations in the anterior faces were estimated based on racial and sexual types utilizing 56 anterior faces. These included 15 males and 13 females of the dolichocranic racial type, and 13 males and 15 females of the brachycranic. Principal component analysis was applied to 6 measurements of the anterior faces for each of

Table 2. Factor loading of the principal components showing both racial and sexual variations in the anterior faces

\begin{tabular}{|c|c|c|c|c|c|c|c|}
\hline Grouping & Females & $\begin{array}{l}\text { Doli } \\
\text { cran }\end{array}$ & $\begin{array}{l}\text { icho- } \\
\text { nics }\end{array}$ & $\begin{array}{l}\text { Brachy- } \\
\text { cranics }\end{array}$ & Males & and $\mathrm{f} f$ & emale \\
\hline easurements and components & 2nd. & 1st. & 2nd. & 1st. & 1st. & 2nd. & $3 \mathrm{rc}$ \\
\hline & & & & & & 12 & $-u$ \\
\hline 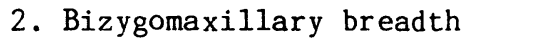 & & 9 & & & & 0.77 & 0.4 \\
\hline - $\mathrm{Gla}$ & 0 . & 0.84 & -0 & & 33 & -0.17 & -0.4 \\
\hline - Nas & & & & & & & -0.2 \\
\hline - Max & & & & & & & 0.3 \\
\hline ale & & 0 & 0. & & 0.46 & 49 & 0.5 \\
\hline
\end{tabular}


the groups. When a component enabled us to discriminate between racial types or between sexual types with statistical significance $(p<0.05)$ by univariate analyses, this was noted and tabulated (Table 2).

\section{Females}

The second component showed a bipolar loading pattern both with two breadth variables in the positive direction, and with one subtense in the negative. The positive were the biorbital and bizygomaxillary breadths, and the negative was the subspinale bizygomaxillary subtense. It represented an axis of shape variation that contrasted the overall widths with the depth of the maxillary region. In females, the average component score $(-0.89)$ of the dolichocranic racial type was smaller than that $(+0.78)$ of the brachycranic $\left(t=4.21^{* * *}\right)$. This component accounted for $29.57 \%$ of the entire variation, while the accumulated proportion of the first three accounted for $83.94 \%$.

\section{Dolichocranics}

The first component showed a unipolar loading pattern with 4 breadth and subtense variables loaded highly in the positive direction. It represented an axis of overall size variation in the frontal region. An average component score of the dolichocranic racial type in males $(+0.89)$ was larger than that of the dolichocranic in females $\left(-1.03, \mathrm{t}^{\prime}=\right.$ $\left.3.94^{* * *}\right)$.

The second component showed a bipolar loading pattern both with two subtense variables in the positive direction, and with two breadth and subtense variables loaded slightly in the negative. The positive were the subspinale bizygomaxillary and maxillofrontale biorbital subtenses, and the negative were the biorbital breadth and glabella biorbital subtense. It represented an axis of shape variation that contrasted the depth of the maxillary and orbital regions with the width and depth of the frontal region. The average component score of the dolichocranic racial type in males $(-0.40)$ was smaller than that of the dolichocranic in females $\left(+0.46, t=2.23^{*}\right)$. The first and second components accounted respectively for $44.98 \%$ and $19.66 \%$ of the entire variation, while the accumulated proportion of the first three accounted for $80.78 \%$.

\section{Brachycranics}

The first component showed a unipolar loading pattern with 4 subtense variables in the positive direction. It represented an axis of size variations in overall depths. An average component score of the brachycranic racial type in males $(+0.79)$ was larger than that of the brachycranic in females $(-0.69$, $\left.\mathrm{t}^{\prime}=2.48^{*}\right)$. This component accounted for $46.02 \%$ of the entire variation, while the accumulated proportion of the first three accounted for $86.06 \%$.

\section{Males and females}

The first component showed a unipolar loading pattern with 4 subtense and breadth variables loaded highly in the positive direction. It represented an axis of overall size variation in the frontal region. Average component scores both for racial and sexual types lined up in descending order were: the brachycranic in males $(+0.98)$, dolichocranic in males $(+0.57)$, brachycranic in females (-0.73), and dolichocranic in females $(-0.79)$. The component scores for the two racial types in males were larger than those for the two in the corresponding females (dolichocranic: $t^{\prime}=3.35^{* *}$, brachycranic : $t^{\prime}=$ 
$\left.2.53^{*}\right)$.

The second component showed a bipolar loading pattern both with two breadth variables in the positive direction, and with one subtense in the negative. The former were the bizygomaxillary and biorbital breadths, and the latter was the subspinale bizygomaxillary subtense. It represented an axis of shape variation that contrasted the overall widths with the depth of the maxillary region. Average component scores both for racial and sexual types lined up in descending order were: the brachycranic in females $(+0.45)$, brachycranic in males $(+0.43)$, dolichocranic in males $(-0.04)$, and dolichocranic in females $(-0.91)$. The component score for the dolichocranic racial type in females was smaller than both that for the dolichocranic in males $(t=2.29 *)$, and that for the brachycranic in females $(t=$ $4.05^{* * *)}$.

Figure 3 shows the similarities in the first two components both between the sexual types, and between the racial types. In the figure, the two racial types in females are plotted on the left, and the two in males on the right. The dolichocranic racial type in females is clustered under the brachycranic in females.

The third component showed a bipolar loading pattern both with two subtense and breadth variables in the positive direction, and with one subtense in the negative. The positive variables were the subspinale bizygomaxillary subtense and bizygomaxillary breadth, and the negative variable was the glabella biorbital subtense. It represented an axis of shape variation that contrasted the width and depth of the maxillary region with the depth of the frontal region. Average component scores both for racial and sexual types lined up in descending order were: the dolichocranic in females $(+0.59)$, brachycranic in females $(-0.11)$, brachycranic in males $(-0.17)$, and dolichocranic in males $(-0.26)$. The component

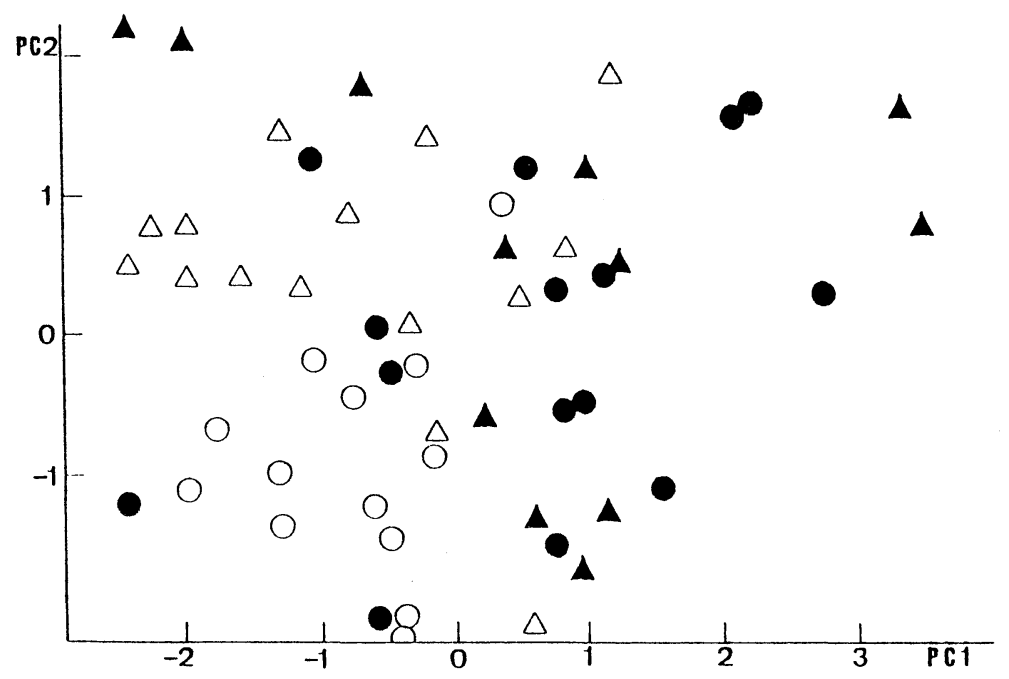

Fig. 3. Similarities in the anterior faces between both racial and sexual types. Black circles show males of the dolichocranic racial type, and white circles females. Black triangles show males of the brachycranic racial type, and white triangles females. 
score of the dolichocranic racial type in females was larger both than that of the dolichocranic in males $\left(t=2.93^{* *}\right)$, and than that of the brachycranic in females $\left(t=2.44^{*}\right)$. The first and second components accounted respectively for $42.98 \%$ and $24.50 \%$ of the entire variation, while the accumulated proportion of the first three accounted for $83.44 \%$.

In females, the dolichocranic racial type was discriminated from the brachycranic by the ratio of the depth of the maxillary region of the anterior face to the overall widths, namely, the horizontal profile of the maxillary region of the anterior face. On the other hand, sexual variations within the two racial types resulted from size differences in the frontal region of the anterior face, and in the dolichocranic racial type, from the ratio of the depth of the frontal region to the width and depth of the maxillary region.

\section{Population characteristics in the face and anterior face}

Two steps were carried out in evaluating population characteristics both for the faces and anterior faces. One was to confirm the racial type based on racial variations both in the faces and anterior faces. Another was to evaluate the racial and sexual differences.

\section{A. Confirmation of racial type}

The skulls from the Himrin Basin had been divided into the two racial types mainly by discriminant functions based on 11 measurements of the skull (WADA, 1986). The function for males showed a bipolar loading pattern both with 5 variables loaded highly in the positive direction, and with three loaded highly in the negative. The positive were the nasal, interorbital, and orbital breadths, the maximum cranial length, and the basion-bregmatic height. The negative were the upper facial and orbital heights and the maximum cranial breadth. This function for females also showed a bipolar loading pattern both with two variables loaded highly in the positive direction and three in the negative. The positive variables were the orbital and basion-bregmatic heights, and the negative were the orbital, maximum cranial, and bizygomatic breadths.

As a result, 32 males and 22 females were classified into the dolichocranic racial type, while 21 males and 20 females were classified as the brachycranic. The skulls of the dolichocranic racial type were characterized metrically according to dolichocranic, acrocranic, mesoconchic, and mesorrhine characteristics. Those of the brachycranic were distinguished by brachycranic, tapeinocranic, hypsiconchic, and leptorrhine characteristics.

In this study, 82 skulls of the original 95 were observed to determine if racial type could be ascertained from the morphology of the face. It was found that racial type could be determined from the face and anterior face.

\section{Males}

The racial variations for males resulted from differences in the horizontal profiles of the maxillary region of the face. A complete set of 13 measurements of the faces and their component scores were obtained for 20 of the dolichocranic samples. Although the racial type was revised for one (IR48), 17 showed component scores in the neighborhood of the average score for the dolichocranic in males. The racial type for one (IR37) of the other three was revised. A complete set of 13 measurements of the 
faces and their component scores were obtained for 15 of the brachycranic samples. Twelve showed component scores in the neighborhood of the average score for the brachycranic in males. The racial type for males could be determined in $82.86 \%$ of the 35 cases. The racial type for two of the dolichocranic samples were revised to the brachycranic.

Six of the dolichocranic samples did not have a complete set of 13 measurements of the face. However, component scores could be obtained by substituting grand mean values of the two racial types in males for the deficient values. Although the racial type was revised for one (IR9), 4 had component scores which were in the neighborhood of the average score for the dolichocranic in males. The racial type for the remaining two (IR29 and IR100) was revised. Even though three of the brachycranic samples did not have a complete set of 13 measurements for the face, component scores were obtained as above. Although one had a component score in the neighborhood of the average score for the brachycranic in males, the racial type was revised for one (IR51) of the other two. The morphology of the face enabled us to distinguish the racial type in $77.78 \%$ of the 9 cases in males. The racial type of 4 samples were revised.

Morphology of the face was valid for classifying the racial type of males in 81.82 $\%$ of the 44 cases. Although racial type was revised in 6 cases, morphology of the skull produced correct results in $86.36 \%$ of the cases.

\section{Females}

Racial variations for females resulted from differences in the horizontal profile of the maxillary region of the anterior face. A complete set of 6 measurements of the anterior faces and their component scores were obtained for 17 of the dolichocranic samples. Although the racial type for one was revised (IR101), component scores in the neighborhood of the average score were obtained for 14 of the dolichocranic in females. The racial type was revised for one (IR145) of the other three. A complete set of 6 measurements of the anterior faces and their component scores were obtained for 20 of the brachycranic samples. Although the racial type was revised for one (IR6), 18 had component scores in the neighborhood of the average for the brachycranic in females.

Morphology of the anterior face enabled us to determine the racial type in $83.78 \%$ of the 37 female cases. The racial type of three cases was revised. Although one of the dolichocranic samples had a deficient set of 6 measurements of the anterior face, a component score could be obtained. It (IR10) had a component score in the neighborhood of the average for the brachycranic in females. Its racial type was revised.

The racial variations in the anterior faces of females showed validity for the classification of $84.21 \%$ of the 38 cases. Although the racial type was revised for 4 cases, racial type division based on the skull was valid $89.47 \%$ of the time.

Eighty-two skulls of the original 95 were observed to check racial type based on the morphology both of the face and anterior face. Although the racial type was revised for 10 cases, racial type division based on the skull was valid $87.80 \%$ of the time.

The remaining 13 for which there were many deficient measurements of the face or anterior face were re-classified according to their previously determined racial type. As 
a result, 28 males and 19 females belonged to the dolichocranic racial type, while 25 males and 23 females were of the brachycranic.

\section{B. Racial and sexual differences in the face and anterior face}

Basic statistics were prepared for racial and sexual differences both in the faces and anterior faces. Twenty-eight cases based on absolute measurements and 15 based on projection indices were utilized for this purpose (Tables 3 and 4 ).

The projection indices were defined as ratios of depth to standard width. They included 8 for the face and 7 for the anterior face. The standard width for the face was the biporionic breadth, and those for the anterior face were the biorbital, simotic, midorbital, and bizygomaxillary breadths. Terminology in the projection indices was the same as that in the subtenses, namely, the nasion projection index for the face or nasion biorbital projection index for the anterior face.

Univariate analyses were applied both to the absolute measurements of the racial and sexual types, and to the projection indices for the face and anterior face. Plates 1 and 2 show a facial view of the two racial type both in males and females.

\section{Males}

The bizygomatic $\left(t=2.88^{* *}\right)$ and biporionic $\left(t=3.05^{* *}\right)$ breadths, upper facial $\left(t=2.19^{*}\right)$ and nasal $\left(t=2.62^{*}\right)$ heights, and total facial $\left(t=2.16^{*}\right)$ and nasalia $\left(t=2.75^{*}\right)$ profile angles of the dolichocranic in males were smaller than those of the brachycranic in males.

The glabella $\left(t=3.03^{* *}\right)$, nasion $\left(t=3.06^{* *}\right)$, rhinion $\left(t=2.12^{*}\right)$, subspinale $\left(t=3.61^{* * *}\right)$, frontotemporale $\left(t=2.54^{*}\right)$, frontomalare $(t=$ $\left.3.48^{* *}\right)$, midorbital $\left(\mathrm{t}=3.61^{* * *}\right)$, and zygomaxillare $\left(t=3.92^{* * *}\right)$ projection indices of the dolichocranic in males were larger than those of the brachycranic in males.

\section{Females}

The bizygomatic $\left(t=6.98^{* * *}\right)$, biporionic $\left(t=6.50^{* * *}\right)$, and biorbital $\left(t=3.69^{* * *}\right)$ breadths, total facial $\left(t^{\prime}=3.19^{* *}\right)$ and nasal $\left(t^{\prime}=3.05^{* *}\right)$ profile angles, and frontotemporale $\left(t=3.84^{* * *}\right)$ and frontomalare $(t=$ $\left.2.87^{* *}\right)$ subteneses of the dolichoranic in females were smaller than those of the brachycranic in females.

In females, the subspinale bizygomaxillary subtense $\left(t=3.74^{* * *}\right)$ of the dolichocranic was larger than that of the brachycranic. Also, the glabella $(t=3.37 * *)$, nasion $(t=$ $\left.3.60^{* * *}\right)$, rhinion $\left(t=2.97^{* *}\right)$, subspinale $(t=$ $\left.5.36^{* * *}\right)$, frontomalare $\left(t=2.60^{*}\right)$, midorbital $\left(\mathrm{t}=2.92^{* *}\right)$, and zygomaxillare $\left(\mathrm{t}=3.21^{* *}\right)$ projection indices, as well as the subspinale bizygomaxillary $\left(t=4.16^{* * *}\right)$ projection index of the dolichocranic were larger than those of the brachycranic.

\section{Dolichocranics}

The bizygomatic $\left(t=5.81^{* * *}\right)$, biporionic $\left(\mathrm{t}^{\prime}=4.28^{* * *}\right)$, and biorbital $\left(\mathrm{t}^{\prime}=3.59^{* *}\right)$ breadths, upper facial $(t=2.79 * *)$ and nasal $\left(t=3.30^{* *}\right)$ heights, glabella $\left(t^{\prime}=6.06^{* * *}\right)$, nasion $\left(t=5.11^{* * *}\right)$, rhinion $(t=4.39 * * *)$, subspinale $\left(t=3.81^{* * *}\right)$, frontotemporale $(t=$ $4.59 * * *)$, frontomalare $\left(t^{\prime}=4.76^{* * *}\right)$, midorbital $(t=4.79 * * *)$, and zygomaxillare $(t=$ $\left.4.51^{* * *}\right)$ subtenses, and glabella $\left(t^{\prime}=5.35^{* * *}\right)$ and nasion biorbital $\left(t=3.50^{* *}\right)$ subtenses of the dolichocranic in males were larger than those of the dolichocranic in females. The glabella $\left(t^{\prime}=4.18^{* * *}\right)$ and nasion biorbital $(t=2.69 *)$ projection indices of the dolichocranic in males were also larger than those 
Table 3. Basic statistics both for the dolichocranic and brachycranic racial types in males

\begin{tabular}{|c|c|c|c|c|c|c|c|}
\hline \multirow[b]{2}{*}{ Item } & \multirow{2}{*}{$\begin{array}{l}\text { Males } \\
\text { Measurements }\end{array}$} & \multicolumn{3}{|c|}{$\begin{array}{l}\text { Dolichocranic } \\
\text { racial type }\end{array}$} & \multicolumn{3}{|c|}{$\begin{array}{l}\text { Brachycranic } \\
\text { racial type }\end{array}$} \\
\hline & & $\mathrm{N}$ & Mean & S.D. & $\mathrm{N}$ & Mean & S.D. \\
\hline & Minimum frontal breadth & 25 & 95.08 & 5.84 & 21 & 98.05 & 4.63 \\
\hline & Biorbital breadth & 21 & 97.91 & 4.84 & 22 & 99.96 & 3.73 \\
\hline 3. & Bizygomaxillary breadth & 21 & 95.31 & 7.31 & 21 & 97.28 & 5.79 \\
\hline 4. & Bizygomatic breadth & 25 & 131.36 & 6.14 & 21 & 136.52 & 5.95 \\
\hline & Biporionic breadth & 21 & 111.75 & 5.90 & 21 & 117.01 & 5.26 \\
\hline & Midorbital breadth & 21 & 54.60 & 4.62 & 20 & 54.82 & 5.75 \\
\hline 7. & Simotic chord & 18 & 10.43 & 2.13 & 20 & 9.82 & 2.32 \\
\hline 8. & Upper facial height & 26 & 68.85 & 4.70 & 23 & 71.65 & 4.21 \\
\hline & Nasal height & 26 & 53.46 & 3.34 & 24 & 55.96 & 3.41 \\
\hline 10. & Total facial profile angle & 20 & 84.45 & 3.20 & 20 & 86.65 & 3.25 \\
\hline 11 . & Nasal profile angle & 23 & 86.61 & 3.27 & 20 & 88.15 & 3.92 \\
\hline 12. & Alveolar profile angle & 19 & 77.74 & 6.44 & 20 & 81.10 & 7.17 \\
\hline 13. & Nasalia profile angle & 11 & 53.45 & 5.34 & 14 & 60.57 & 7.15 \\
\hline 14. & Glabella subtense & 21 & 101.31 & 5.47 & 21 & 100.05 & 4.38 \\
\hline 15 . & Nasion subtense & 21 & 96.71 & 5.12 & 21 & 95.18 & 4.65 \\
\hline 16. & Rhinion subtense & 10 & 104.20 & 5.16 & 15 & 102.97 & 5.86 \\
\hline 17. & Subspinale subtense & 20 & 99.18 & 4. & 21 & 96.78 & 4.56 \\
\hline 18. & Frontotemporale subtense & 21 & 84.77 & 4.86 & 21 & 85 & 4.28 \\
\hline 19. & Frontomalare subtense & 21 & 77.51 & 4.90 & 21 & 76.33 & 3.70 \\
\hline 20. & Midorbital subtense & 20 & 82.92 & 4.08 & 20 & 81.22 & 3.34 \\
\hline 21 . & Zygomaxillare subtense & 20 & 75.47 & 4. & 21 & 74 & 3.11 \\
\hline 22 . & Glabella biorbital subtense & 21 & 25.53 & 2 . & 22 & 24.31 & 4.11 \\
\hline 23. & Nasion biorbital subtense & 21 & 20.21 & 2.57 & 22 & 18.92 & 3.65 \\
\hline 24. & Rhinion biorbital subtense & 11 & 34.93 & 3.40 & 15 & 34.38 & 3.71 \\
\hline 25 . & Subspinale bizygomaxil. sub. & 21 & 24.20 & 3. & 21 & 23.29 & 3.73 \\
\hline 26. & Maxillofrontale biorbit. sub. & 20 & 11.96 & 2. & 21 & 12.16 & 6.41 \\
\hline 27. & Rhinion midorbital subtense & 11 & 24.02 & 2.79 & 14 & 22.39 & 4.91 \\
\hline 28. & Simotic subtense & 17 & 5.43 & 1.25 & 20 & 5.19 & 1.30 \\
\hline 1. & on index & 21 & 9 & & 21 & & 5.90 \\
\hline & Nasion projection index & 21 & 86.67 & 4. & 21 & 81.54 & 6.00 \\
\hline & Rhinion projection index & 10 & 94.05 & 5.34 & 15 & 87.93 & 7.99 \\
\hline 4. & Subspinale projection index & 20 & 89.11 & 5.11 & 21 & 82.91 & 5.84 \\
\hline 5. & Frontotemporale projec. in. & 21 & 75.95 & 4.18 & 21 & 72.94 & 3.48 \\
\hline & Frontomalare projection in. & 21 & 69.44 & 4. & 21 & 65.31 & 3.54 \\
\hline 7 . & Midorbital projection index & 20 & 74.48 & 3.75 & 20 & 69.69 & 4.61 \\
\hline 8. & Zygomaxillare projection in. & 20 & 67.76 & 3.30 & 21 & 63.43 & 3.74 \\
\hline 9. & Glabella biorbit. projec. in. & 21 & 26.05 & 2.35 & 22 & 24.35 & 4.14 \\
\hline 10. & Nasion biorbit. projec. in. & 21 & 20.60 & 2.07 & 22 & 18.93 & 3.57 \\
\hline 11 . & Rhinion biorbit. projec. in. & 11 & 35.55 & 2.61 & 15 & 34.48 & 3.80 \\
\hline 12. & Subspinale bizygo. projec. in. & 21 & 25.42 & 3.43 & 21 & 24.00 & 4.00 \\
\hline 13. & Maxillofrontale bior. pro. in. & 20 & 12.16 & 2.34 & 21 & 12.09 & 6.16 \\
\hline 14. & Rhinion midorbital projec. in. & 11 & 45.03 & 4.22 & 14 & 42.12 & 8.55 \\
\hline 15. & Simotic projection index & 17 & 51.64 & 9.07 & 20 & 53.54 & 11.26 \\
\hline
\end{tabular}


Table 4. Basic statistics both for the dolichocranic and brachycranic racial types in females

\begin{tabular}{|c|c|c|c|c|c|c|c|}
\hline & Females & & $\begin{array}{l}\text { lichocra } \\
\text { acial ty }\end{array}$ & $\begin{array}{l}\text { anic } \\
\text { ype }\end{array}$ & & $\begin{array}{l}\text { achyc } \\
\text { cial }\end{array}$ & \\
\hline Item & Measurements & $\mathrm{N}$ & Mean & S.D. & $\mathrm{N}$ & Mean & S.D. \\
\hline & Minimum frontal breadth & 18 & 92.11 & 3.92 & 19 & 94.63 & 5.01 \\
\hline & Biorbital breadth & 15 & 93.43 & 2.59 & 23 & 97.11 & 3.25 \\
\hline & Bizygomaxillary breadth & 15 & 92.33 & 4.99 & 23 & 94.05 & 3.99 \\
\hline & Bizygomatic breadth & 16 & 121.00 & 4.53 & 23 & 130.96 & 4.28 \\
\hline & Biporionic breadth & 14 & 105.16 & 3.16 & 21 & 113.99 & 4.36 \\
\hline & Midorbital breadth & 15 & 54.13 & 4.96 & 23 & 54.38 & 4.20 \\
\hline & Simotic chord & 14 & 9.72 & 2.40 & 22 & 9.63 & 3.16 \\
\hline & Upper facial height & 17 & 64.88 & 4.33 & 23 & 66.00 & 4.42 \\
\hline & Nasal height & 17 & 49.82 & 3. & 23 & 04 & 4.59 \\
\hline 10 . & Total facial profile angle & 12 & 82.58 & 5. & 19 & 88 & 3.00 \\
\hline 11. & Nasal profile angle & 14 & 84.79 & 5.32 & 21 & 57 & 3.04 \\
\hline 12. & Alveolar profile angle & 11 & 73.64 & 13.43 & 19 & 80.79 & 8.08 \\
\hline 13. & Nasalia profile angle & 11 & 58.09 & 8. & 13 & & 6.88 \\
\hline 14. & Glabella subtense & 14 & 92.51 & 3. & 20 & 92 & 3.97 \\
\hline 15. & Nasion subtense & 14 & 88.89 & 3.10 & 21 & & 3.88 \\
\hline 16. & Rhinion subtense & 11 & 95.19 & 4.25 & 13 & 97.13 & 3.28 \\
\hline 17. & Subspinale subtense & 14 & 93.43 & & 20 & & 3.89 \\
\hline 18. & Frontotemporale & 13 & 77.56 & 3. & 19 & & 3.13 \\
\hline 19. & Frontomalare sub & 14 & 71.49 & 2. & 21 & 74 & 3.13 \\
\hline 20. & Midorbital subtense & 14 & 76.73 & 3. & 21 & 78.77 & 3.37 \\
\hline 21 . & Zygomaxillare $s$ & 14 & 40 & & 21 & & 3.31 \\
\hline 22 . & Glabella biorbital & 15 & 21.90 & 1 . & 22 & 21 & 2.73 \\
\hline 23. & Nasion biorbit & 15 & 17.61 & 1 . & 23 & 17.25 & 2.29 \\
\hline 24. & Rhinion biorbital subtense & 11 & 31.59 & 4.57 & 15 & 31.40 & 2.13 \\
\hline 25. & Subspinale bizygomaxil. sub. & 15 & 24.65 & & 22 & & 2.59 \\
\hline 26. & Maxillofrontale bior & 14 & 11.77 & 1. & 23 & & 2.69 \\
\hline 27. & Rhinion midorbital subtense & 11 & 20.34 & 5. & 15 & 19 & 1.98 \\
\hline 28. & Simotic subtense & 13 & 4.43 & 1.46 & 22 & .04 & 1.15 \\
\hline 1 . & & 14 & & & 20 & & 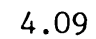 \\
\hline & $n$ pro & 14 & 52 & 4 & 21 & & 3.71 \\
\hline & Rhinion projection index & 11 & 90.47 & 4.45 & 13 & 85.52 & 3.72 \\
\hline & Subspinale projection index & 14 & 88.95 & 4.57 & 20 & 80.72 & 4.29 \\
\hline & Frontotemporale projec. in. & 13 & 73.96 & 4. & 19 & & 3.23 \\
\hline & Frontomalare projection in. & 14 & 68.05 & 3. & 21 & 9 & 2.77 \\
\hline 7. & Midorbital projection index & 14 & 73.08 & 4.48 & 21 & 69.18 & 3.43 \\
\hline 8. & Zygomaxillare projection in. & 14 & 66.09 & 4.47 & 21 & 61.93 & 3.20 \\
\hline 9. & Glabella biorbit. projec. in & 15 & 23.45 & 1.36 & 22 & 22.63 & 2.61 \\
\hline 10. & Nasion biorbit. projec. in. & 15 & 18.86 & 1.70 & 23 & 17.75 & 2.2 \\
\hline 11. & Rhinion biorbit. projec. in. & 11 & 33.94 & 5.24 & 15 & 32.32 & 2.32 \\
\hline 12. & Subspinale bizygo. projec. in. & 15 & 26.73 & 2.36 & 22 & 22.99 & 2.87 \\
\hline 13. & Maxillofrontale bior. pro. in. & 14 & 12.63 & 2.04 & 23 & 11.03 & 2.76 \\
\hline & Rhinion midorbital projec. in. & 11 & 38.56 & 10.24 & 15 & 36.91 & 4.20 \\
\hline 15. & Simotic projection index & 13 & 44.69 & 10.16 & 22 & 44.10 & 12.22 \\
\hline
\end{tabular}



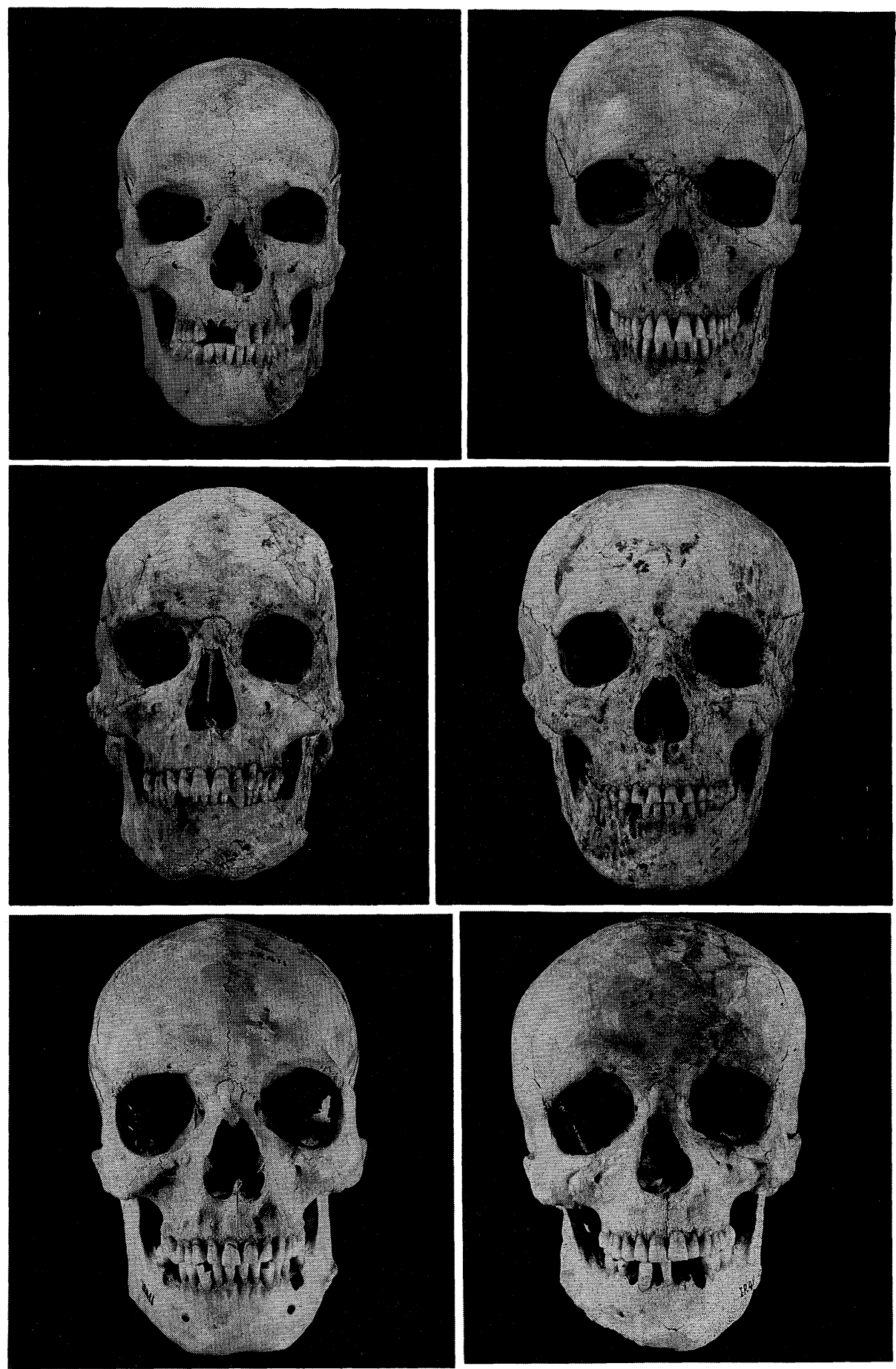

Plate 1. Facial view of both dolichocranic and brachycranic racial types in males. The left half shows dolichocranic males, and the right brachycranic males. 

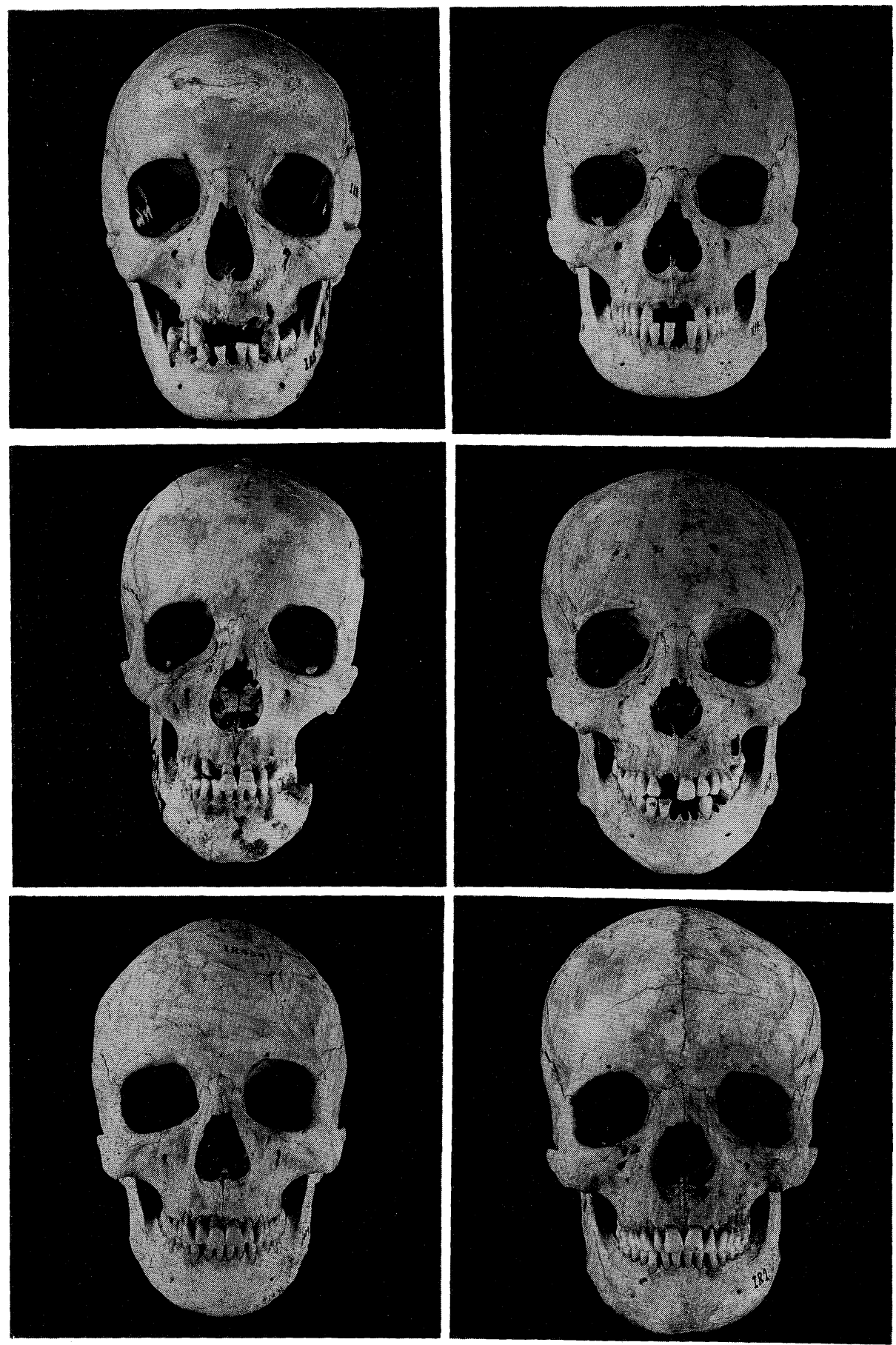

Plate 2. Facial view of both dolichocranic and brachycranic racial types in females. The left half shows dolichocranic females, and the right brachycranic females. 
of the dolichocranic in females.

\section{Brachycranics}

The minimum frontal $\left(t=2.24^{*}\right)$, bizygomatic $\left(t=3.59^{* * *}\right)$, biporionic $\left(t=2.03^{*}\right)$, biorbital $\left(\mathrm{t}=2.73^{* *}\right)$, and bizygomaxillary $\left(\mathrm{t}=2.17^{*}\right)$ breadths, upper facial $\left(\mathrm{t}=4.44^{* * *}\right)$ and nasal $\left(t=3.33^{* *}\right)$ heights, glabella $(t=$ $\left.3.92^{* * *}\right)$, nasion $\left(\mathrm{t}=3.25^{* *}\right)$, rhinion $\left(\mathrm{t}^{\prime}=\right.$ $\left.3.30^{* *}\right)$, subspinale $\left(t=3.80^{* * *}\right)$, frontotemporale $\left(t=2.56^{*}\right)$, midorbital $\left(t=2.33^{*}\right)$, and zygomaxillare $\left(t=3.59^{* * *}\right)$ subtenses, glabella $\left(t=2.23^{*}\right)$ and rhinion biorbital $\left(t^{\prime}=2.70^{*}\right)$ subtenses, and simotic $\left(t=3.04^{* *}\right)$ subtense of the brachycranic in males were larger than those of the brachycranic in females. The simotic projection index $\left(t=2.60^{*}\right)$ of the brachycranic in males was also larger than that of the brachycranic in females.

Racial type in males was determined mainly by the width of the postero-basal region of the face, namely, the bizygomatic and biporionic breadths. On the other hand, in females this was determined both by the depth of the maxillary region of the anterior face, namely, the subspinale bizygomaxillary subtense, and by the width of the posterobasal region of the face. The sexual variations of both were determined mainly by overall size differences both in the face, and in the frontal region of the anterior face.

\section{Racial positions of Himrin racial types in the world}

Two types of facial profiles for the two racial types from the Himrin Basin were compared with those for world populations. The first type included horizontal profiles of the anterior face. Comparative populations which included a total of 26 Mongoloid and Caucasoid races were quoted from Yamaguchi (1973). The second type included vertical profiles of the face. The comparative populations, which included Mongoloid, Caucasoid, Negroid, and Australoid races were quoted from MARTIN and SALLER (1959).

Principal component analysis was applied to the data of those respective populations to investigate the racial positions of the two racial types in the world.

\section{A. Comparisons based on horizontal profiles of the anterior face}

YAMAGUCHI (1973) reviewed the literature on horizontal profiles of the anterior face since the original study by WoO and MORANT (1934). The data were composed of three facial flatness indices. The indices represented the horizontal profiles of the frontal region, nasal bridge, and maxillary region as the frontal, simotic, and zygomaxillary indices.

The flatness indices corresponded to the nasion biorbital, simotic, and subspinale bizygomaxillary projection indices in the present paper. In females, the dolichocranic racial type was distinguished from the brachycranic merely by the subspinale bizygomaxillary projection index.

\section{Racial comparisons}

The first component showed a unipolar loading pattern with three index variables in the positive direction, namely, the nasion biorbital (0.97), subspinale bizygomaxillary (0.91), and simotic (0.89) projection indices. It represented an axis of size variation in projection of the anterior face. When the populations tended to show projection of the three regions, high component scores were obtained.

The second component showed a bipolar loading pattern both with the simotic projec- 


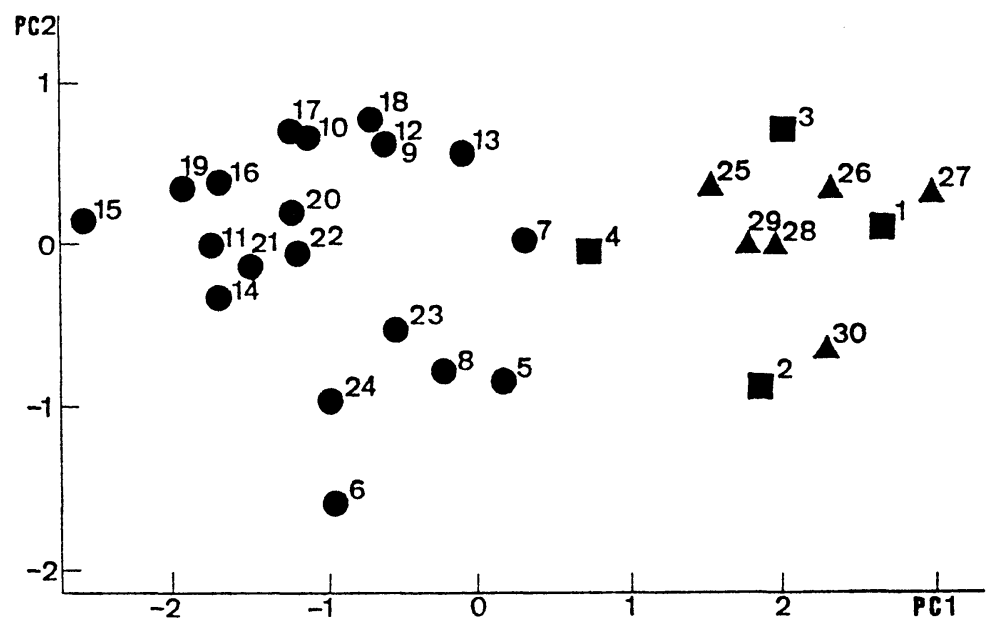

Fig. 4. Affinities between the two racial types and the Mongoloid and Caucasoid races according to horizontal profiles of the anterior face. All the comparative populations are quoted from YAMAGUCHI (1973). Black squares show the racial and sexual types from the Himrin Basin. Their superscripts are : $1=$ dolichocranic male, $2=$ dolichocranic female, $3=$ brachycranic male, and $4=$ brachycranic female. Black circles show populations of the Mongoloid race. The superscripts are: $5=$ Japanese male, $6=$ Japanese female, 7 =Hokkaido Ainu male, 8=Hokkaido Ainu female, $9=$ Eskimo, pooled, $10=$ Chukchi, pooled, 11=Yukaghir, 12=Gilyak (Nivkhi), 13=Sakhalin Ainu, 14=Ulchi, $15=$ Tungus, $16=$ Buryat, pooled, $17=$ Mongol, $18=$ Kalmuk, $19=$ Soyot (Tuvintsy), $20=$ Telenget, $21=$ Yakut, $22=$ Samoyed (Nentsy), $23=$ Ostiak (Khanty), and $24=$ Chinese. Black triangles show populations of the Caucasoid race. The superscripts are: $25=$ Uzbeg, $26=$ Ossetian, 27=Armenian, $28=$ Russian, $29=$ Medieval Russian, and $30=$ Italian.

tion index (0.45) in the positive direction, and with the subspinale bizygomaxillary projection index $(0.39)$ in the negative. It represented the morphological pattern between the nasal bridge and the maxillary region. When the populations tended to show features of the two regions divergent from the average for all populations, high component scores were obtained in the positive or negative direction.

Figure 4 shows the affinity in the first two components between the two racial types from the Himrin Basin and the world Mongoloid and Caucasoid races. In the figure, the 20 in the Mongoloid race are plotted on the left place, and the 6 in the
Caucasoid on the right. The two racial types from the Himrin Basin are located in the cluster of the Caucasoid race. Japanese, Hokkaido Ainu, and the two Himrin racial types have the data for both sexes. Those populations in males tend to obtain higher scores for the first two components than the corresponding ones in females.

The first component accounted for $85.14 \%$ of the entire variation, while the accumulated proportion of the first two accounted for $96.86 \%$.

The anterior faces of the two racial types from the Himrin Basin were more similar to those of the world Caucasoid race than to those of the Mongoloid race. 


\section{B. Comparisons based on vertical profiles of the face}

MARTIN and SALLER (1959) reviewed the literature on vertical profiles of the face. The data were derived from studies that defined the face as a pre-auricular structure. They were composed of three prognathism indices. The indices represented the vertical profiles of the overall face, nasal region, and alveolar region as the total facial, nasal, and alveolar profile angles.

In males, the dolichocranic racial type was discriminated from the brachycranic by the total facial profile angle. On the other hand, the two racial types in females were distinguished both by the total facial angle, and by the nasal profile angle.

\section{Racial comparisons}

The first component showed a unipolar loading pattern with three variables in the positive direction, namely, the total facial (0.99), nasal (0.94), and alveolar (0.93) profile angles. It represented an axis of size variation in prognathism of the face. When the populations tended to show orthognathism of the three regions, they had high component scores.

The second component showed a bipolar loading pattern both with the alveolar profile angle (0.36) in the positive direction, and with the nasal profile angle (0.33) in the negative. It represented a morphological pattern between the nasal region and the alveolar region. When the populations tended to show features of the two regions divergent from the average for all populations, they showed high component scores in the positive or negative direction.

Figure 5 shows the affinity in the first two components between the two racial

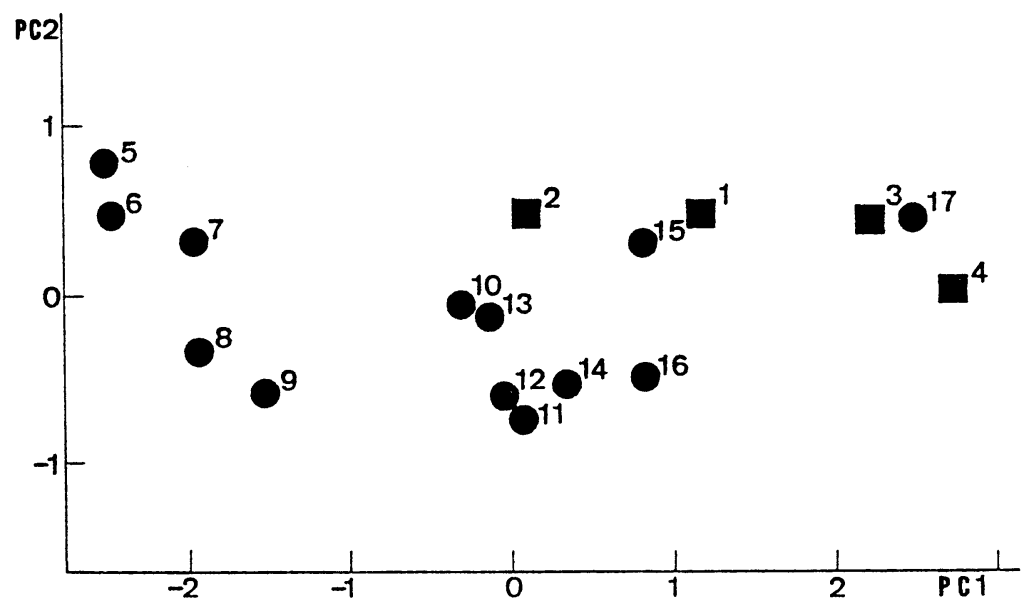

Fig. 5. Affinities between the two racial types and the Mongoloid, Caucasoid, Negroid, and Australoid races according to vertical profiles of the face. All comparative populations are quoted from MARTIN and SALLER (1959). Black squares show the racial and sexual types from the Himrin Basin. The superscripts are: $1=$ dolichocranic male, 2 =dolichocranic female, $3=$ brachycranic male, and $4=$ brachycranic female. Black circles show world populations. The superscripts are : $5=$ Australier, $6=P a p u a$, $7=$ Kamerun-Neger, $8=$ Nordostafrikanische Neger, $9=$ Dschagga, 10=Tamilen, $11=$ Battak, 12=Birmanen, 13=Singhalesen, 14=Chinesen, 15=Altägypter, 16=Wedda, and $17=$ Schweizer (Bündner). 
types from the Himrin Basin and the world Mongoloid, Caucasoid, Negroid, and Australoid races. The 6 Mongoloid populations are in the center of the lower region, and the 5 in the Australoid and Negroid populations towards the left. The two racial types in this study are towards the right of the upper region beside the two Caucasoid populations. In both sexes, the brachycranic racial type show higher first component scores than the dolichocranic. The former are located near the Switzerland population in the Caucasoid race, while the latter are placed near the Egypt population in the Caucasoid race.

The first component accounted for $92.04 \%$ of the entire variation, while the accumulated proportion of the first two accounted for $99.84 \%$.

The faces of the two racial types from the Himrin Basin were more similar to those of the world Caucasoid race than to other races. The comparative studies both on the anterior face and on the face indicated that the dolichocranic and brachycranic racial types from the Himrin Basin belonged to the Caucasoid race. The studies also emphasized that the racial differences observed both in the faces and anterior faces were due simply to intra-racial variation in the Caucasoid race.

\section{Discussion}

As stated in the introduction, this study is an extension of previous work (WADA, 1986). One reason for this additional study of the facial skeleton is that the previous studies analyzed facial profiles only based on the front, namely, using width and height measurements of the facial skeleton. This was because a number of comparative works on the front of the skull are available in West Asian anthropology.

As a result, the facial skeletons for the dolichocranic racial type were discriminated from those for the brachycranic by ratios of the height of the orbits to the width both of the nasal root and anterior nasal aperture. This result simply suggests that the facial skelectons for the two racial types can be discriminated by profiles of the facial organs contained in the facial skeleton rather than profiles of the facial skeleton. Although it is certainly important to evaluate the profiles of the facial organs, we must first of all thoroughly study profiles of the facial skeleton. At the same time, it has been suggested that we should study both the extent and profiles of the cranial and facial skeletons for the purpose of evaluating the affinity between the dolichocranic and brachycranic racial types in West Asia (KEITH, 1927 ; FüRST, 1939).

In order to clarify the extent of the facial skeleton, this study first defined the facial skeleton as the front of the skull. The front, termed the face, was separated from the cranial skeleton by a plane connecting the supraorbital margin and external acoustic meatus on each side. Since the face is polyhedral, it was further divided into the face proper and its front. The front, distinguished by the anterior face, was separated by a plane connecting the frontomalare orbitale and zygomaxillare anterius on each side. A protocol was designed to study horizontal profiles both of the face and anterior face. Methods both for providing quantitative expression and studying horizontal profiles are provided both by facial flatness measurements (WoO and MORANT, 1934 ; YAMAGUCHI, 1973, 1980 ; Dodo, 1986), and by the radii from facial landmarks to the transmeatal axis (Howells, 1973). 
The first study to estimate morphological variations both in the faces and anterior faces showed that the dolichocranic racial type in males was discriminated from the brachycranic in males by the ratio of the depth of the maxillary region of the face to the overall widths. The two racial types in females were distinguished by the ratio of the depth of the maxillary region of the anterior face to the overall widths. On the other hand, sexual variations within racial types resulted mainly from overall size differences both in the face, and in the frontal region of the anterior face. The results indicated that the two racial types could be discriminated by profiles of the facial skeleton, namely, horizontal profiles of the face and anterior face.

One motive for checking the racial type division due to the morphology of the skull was the fact that the prime discriminator had been the upper and back contours of the cranial skeleton. In addition, we felt that this was necessary in order to pursue studies to confirm racial type by other skeletal discriminators.

Eighty-two skulls from the Himrin Basin were observed to check racial type based on racial variations both in the faces and anterior faces. Although the racial type for 10 smaples was revised, the racial type was correct in $87.80 \%$ of the cases. At the same time, racial variations both in the faces and anterior faces were valid for classification in $82.93 \%$ of the cases. It can be inferred that the horizontal profiles of the face and anterior face, as well as the upper and back contours of the cranial skeleton, are both discriminators for the classification.

The next study will evaluate the population characteristics both in the face and anterior face. Previous studies showed that the dolichocranic racial type was characterized metrically by dolichocranic, acrocranic, mesoconchic, and mesorrhine characteristics in the skull. On the other hand, the brachycranic was distinguished by brachycranic, tapeinocranic, hypsiconchic, and leptorrhine characteristics.

The present studies found that the dolichocranic racial type had more projecting faces than the brachycranic. A projecting face may be described as the contrast between the nearly square-shaped profile of the dolichocranic and the trapezoid-shaped profile of the brachycranic. In other words, the contrast results mainly from size differences in the width of the postero-basal region of the face, namely, the cranial base. These results may indicate that the horizontal profiles of the face are strongly affected by contours of the cranial skeleton. The interactions of cause and effect should be further analyzed.

At the same time, the present study found that the dolichocranic racial type in females had a more projecting anterior face in the maxillary region than the brachycranic in females. The projecting anterior face may be described as a contrast between a triangleshaped profile of the dolichocranic and the more obtuse triangle-shaped profile of the brachycranic. The contrast in the horizontal profile comes chiefly from size differences in the depth of the maxillary region.

One motive for investigating the racial positions in the world of the two racial types from the Himrin Basin was geographic. West Asia is bordered on the northeast by areas inhabited by the Mongoloid race, namely, the Brachycranic race. Previous comparative studies have mainly shown racial positions in West Asia. As a 
result, the dolichocranic racial type belonged to the Mediterranean race of the Caucasoid race. On the other hand, the brachycranic belonged to the Alpine. The present comparative study was planned specifically to show the affinity between the brachycranic racial type and Brachycranic race.

The two racial types from the Himrin Basin were compared with world populations both by horizontal profiles of the anterior face, and by vertical profiles of the face. All the comparative works were quoted both from MARTIN and SALLER (1959), and from YAMAGUCHI (1973). Those profiles are regarded as powerful tools for discriminating between the Mongoloid and Caucasoid races in the world (WOO and MORANT, 1934; MARTIN and SAller, 1959; YAMAGUCHI, 1973; DoDo, 1986).

The present study showed that the two racial types from the Himrin Basin belonged to the Caucasoid race. At the same time, comparison by the vertical profiles of the face produced meaningful results. The dolichocranic racial type was similar to the Egypt population, while the brachycranic resembled the Switzerland population. These results indicated that the two racial types are members of the Caucasoid race. The dolichocranic belongs to the Mediterranean race, while the brachycranic belongs to the Alpine. In addition, it can be inferred that the brachycranic racial type has facial features basically different from the Brachycranic race.

From the present studies, it can be concluded that inter-racial variations between the dolichocranic racial type and the brachycranic racial type, observed both in the faces and in the anterior faces, are an intraracial variation in the Caucasoid race.

\section{Acknowledgments}

I would like to express my gratitude to Dr. J. IKEDA of Okayama University of Science, and Dr. S. KANDA of Hyogo College of Medicine for their permission to study the Himrin human skeletal remains. I would also like to express my special gratitude to Dr. S. Matano of Osaka University, Drs. K. Katayama and S. Kuroda of Kyoto University, and Dr. H. FuJII of Kokushikan University for their constant support and encouragement in studying the Himrin skeletal remains following excavation in 1978-80. Thanks must be given to Messrs. K. Hamada, M. Yagi, and Y. Matsubara, and to Mmes. F. Endo, K. TOYodA, and M. WADA, of Hyogo College of Medicine for their technical assistance in compiling the large body of data on the Himrin skeletal remains.

抄 録
イラク・ハムリン顔而頭蓋の水平輪郭


和田洋

この報告はイラク・ハムリン盆地から出土した顔面 頭蓋の水平輪郭を記載している. 顔面頭蓋㧍よびその 前部の水平輪郭が前後径および幅径の22項目で分析さ れた，顔面頭蓋は眼窩上縁および外耳孔の 4 点を結ぶ 平面より前下方の部と, また顔面頭蓋前部は frontomalare orbitale および zygomaxillare anterius の 4 点を結ぶ平面より前方の部と定められた。資料は長 頭（地中海人種）および短頭集団（アルプス人種）に 所属する95例であり, 方法は単変量および主成分分折 を用いた。目的は集団間および性間の形態变異を推定 し，その集団間変異に基づいて集団分類を確立するこ とであり，また集団特徵を明らかにし，その集団特徵 に基づいてハムリン両集団の世界の中における人種的 位㯰を確立することである。

主成分分析では，男性の長頭および短頭集団間が顔 
面頭蓋上顎部の水平輪郭により，また女性のそれが顔 面頭蓋前部の上顎部水平輪郭により特徵づけられた。

一力, 両集団の性間変異は主に顔面頭蓋全体と顔面頭 蓋前部の前頭部との大きさにより特徴づケられた。顔 面頭蓋の集団間変異に基づく観察により，82例の頭蓋 が所属する集団型を再吟味した。その結果, 前回（和 田，1986）の集団分類法は88\%で正しく，一方今回の それは83\%の正当率であった，前回および今回の集団 閏変異に基づいて，10例の集団型が変更された。単変 量解析では，男性の集団間変異が顔面頭蓋後方底部す なわち頭蓋底の幅径の差異により，また女性のそれが 顔面頭蓋前部の上顎部長径と頭蓋底の幅径との雨者の 差異により生じていた。主成分分析を用いていムリン 雨集団の人種的位置を確認すると, 長頭および短頭集 団はいずれもコーカソイドの一員であることが示唆さ れた。

\section{References}

Brothwell, D.R., 1981: Digging up Bones. British Museum. Cornell Univ. Press, New York, pp. 59-63.

DoDo, Y., 1986: A study of the facial flatness in several cranial series from East Asia and North America. J. Anthrop. Soc. Nippon, 94 : 81-93.

EHRICH, R. W., 1939: Late cemetery crania. In : Nuzi, vol. I (by F.R.S. STARR). Harvard Univ. Press, Massachusetts, pp. 570-589.

El-NajJar, M. Y. and K.R. McWilliams, 1978: Forensic Anthropology. Thomas, Illinois, pp.
55-85.

FujII, H., 1981: Preliminary report of excavations at Gubba and Songor. In: Al-Ráfidán, vol. II. The Institute for Cultural Studies of Ancient Iraq, Kokushikan Univ., pp. 1-246.

FürsT, C. M., 1939: The skeletal material collected during the excavation of Dr. T.J. ARNE in Shah Tepe at Astrabad-Gorgan in Iran. Bokforlags Aktiebolaget Thule, Stockholm, pp. 13-34.

Howells, W. W., 1973: Cranial variation in Man. Peabody Mus. Pap., 67. Harvard Univ., Massachusetts, pp. 159-190.

KEITH, S. A., 1927 : Report on the human remains. In: Ur Excavations, vol. I, Al-Ubaid (by HALL, H. R. and C. L. Woolley). Oxford Univ. Press, London, pp. 225-240.

Martin, R. and K. SAller, 1957, 1959: Lehrbuch der Anthropologie. Gustav Fischer, Stuttgart, pp. 429-518 and 1377-1393.

WADA, Y., 1986: Anthropological studies on the skulls of the Islamic period, unearthed in the Himrin Basin, Iraq. Anthropological Report, 43: 1-32. (In Japanese with English summary)

Woo, T.L. and G.M. MORANT, 1934: A biometrical study of the "Flatness" of the facial skeleton in Man. Biometrika, $26: 196-250$.

Yamaguchi, B., 1973: Facial flatness measurements of the Ainu and Japanese crania. Bull. Natn. Sci. Mus., 16: 161-171.

YAMAGUCHI, B., 1980: A study on the facial flatness of the Jomon crania. Bull. Natn. Sci. Mus., 6: 21-28.

\section{和 田 洋兵簐医科大学解剖学第二講坐} 干663 西宮市武瑓川町 1-1

Yo WADA

Department of Anatomy, Hyogo College of Medicine 1-1 Mukogawa-cho, Nishinomiya-shi, Hyogo 663, Japan 